\title{
ANALISIS KEMAMPUAN ABSTRAKSI MATEMATIS SISWA DALAM MENYELESAIKAN SOAL PADA MATERI SEGIEMPAT KELAS VII SMP
}

\author{
Alfin Lushfatun Nisa ${ }^{1}$ \\ ${ }^{1}$ Guru Matematika MTs Persiapan Kecamatan Kemlagi Kabupaten Mojokerto \\ E-mail: ${ }^{1}$ alfinlushfa24@gmail.com
}

\begin{abstract}
Abstrak
Penelitian ini bertujuan untuk mendeskripsikan kemampuan abstraksi matematis siswa dalam menyelesaikan soal pada materi segiempat kelas VII semester genap di MTs Persiapan Kecamatan Kemlagi Kabupaten Mojokerto. Penelitian ini menggunakan pendekatan kualitatif dan jenis penelitian deskripsi. Subjek penelitiannya adalah siswa kelas VIII-A MTs Persiapan Kecamatan Kemlagi Kabupaten Mojokerto, kemudian dipilih tiga siswa sebagai subjek penelitian yang didasarkan pada tingkat kemampuan matematis siswa, yaitu tinggi, sedang, dan rendah. Sebelum dianalisis, dilakukan pengecekan keabsahan data dengan triangulasi teknik, yaitu membandingkan antara hasil tes dengan wawancara. Hasil penelitian menunjukkan bahwa kemampuan abstraksi matematis siswa pada materi segiempat berdasarkan kriteria level-level abstraksi yang meliputi level pengenalan (recognition), level representasi (representation) dan level abstraksi struktural (structural abstraction). Siswa dengan kemampuan matematis tinggi dapat menggunakan kemampuan abstraksi dengan baik, yaitu mampu mencapai ketiga level. Siswa dengan kemampuan sedang dapat menggunakan kemampuan abstraksi pada ketiga level di dua soal dan di empat soal yang lain hanya mampu mencapai level pengenalan dan representasi. Sedangkan siswa dengan kemampuan matematis rendah dalam menggunakan kemampuan abstraksi masih kurang baik dengan hanya mampu mencapai level pengenalan dalam menyelesaikan soal.
\end{abstract}

Kata Kunci: kemampuan abstraksi, menyelesaikan soal, segiempat

\section{PENDAHULUAN}

Matematika merupakan salah satu cabang ilmu yang sangat penting karena matematika sangat diperlukan untuk kehidupan sehari-hari dan menjadi dasar bagi cabang ilmu yang lain. Matematika diajarkan di semua jenjang pendidikan dan merupakan salah satu penentu kelulusan siswa. Namun sangat memperhatinkan jika melihat kenyataan bahwa matematika menjadi suatu mata pelajaran yang dianggap sulit oleh banyak siswa. Salah satu hal yang menyebabkan adanya pandangan negatif terhadap matematika adalah karena matematika merupakan ilmu yang abstrak. Hal ini sesuai dengan pendapat yang dikemukakan oleh Nurhasanah (2010) bahwa matematika adalah sebuah ilmu dengan objek kajian yang bersifat abstrak.

Menurut Ge \& Land (Hong \& Kim : 2016), masalah tidak terstruktur membuat siswa mengaitkan pengetahuan matematika abstrak dengan kehidupan sehari-hari. Dengan demikian siswa mampu berpikir abstrak, menggeneralisasi, dan menyusun masalah dalam kehidupan sehari-hari. Kemampuan abstraksi siswa merupakan hal yang sangat penting. Setiap siswa memiliki kemampuan abstraksi dalam menyelesaikan permasalahan pada pelajaran 
matematika dalam menyelesaikan soal yang berbeda-beda sesuai dengan tingkat kemampuan berfikir dan intelegensi siswa sendiri. Hal ini memang belum banyak disadari oleh sebagian orang. Oleh karena itu peneliti tertarik untuk mengadakan penelitian tentang kemampuan abstraksi pada siswa sekolah menengah pertama. Kemampuan abstraksi siswa pada tingkat sekolah menengah pertama merupakan tingkatan penting dalam pondasi berfikir abstrak lebih lanjut. Karena pada tingkatan ini, materi-materi yang disajikan merupakan materi dasar yang lebih kompleks serta banyak materi-materi baru yang nantinya digunakan dalam tingkatan lanjutan.

Geometri merupakan salah satu cabang matematika yang mempelajari objek-objek seperti titik, garis, bidang, ruang, beserta hubungan-hubungannya, yang keseluruhan objeknya bersifat abstrak. Materi Geometri dalam matematika SMP meliputi garis, sudut, bangun datar, kesebangunan, bangun ruang, dan pythagoras. Dalam penelitian ini peneliti menfokuskan pada materi segiempat. Pembahasan tentang materi segiempat tidak akan berhenti pada tingkatan sekolah menengah pertama saja, karena materi segiempat ini nantinya akan berkembang lebih kompleks pada tingkatan selanjutnya. Sehingga pemahaman konsep awal yang mendalam tentang materi ini sangat diperlukan. Jika sejak awal anak didik telah memahami dan mampu mengabstraksikan soal khususnya pada materi segiempat ini, maka akan memudahkan pada tingkatan selanjutnya.

Berdasarkan hasil wawancara dengan guru bidang studi matematika yang dilakukan peneliti sebelum penelitian ditemukan adanya kendala berupa pengajar bidang studi matematika di sekolah tersebut bukanlah pengajar yang berlatar belakang jurusan matematika, sehingga pembelajaran matematika dapat dikatakan belum maksimal karena pengajar bukan orang yang berkecimpung secara penuh dalam dunia pendidikan matematika. Sedangkan kemampuan abstraksi merupakan salah satu bagian penting dalam pembelajaran matematika.

Dengan adanya kenyataan tersebut, tujuan penelitian ini adalah mendeskripsikan kemampuan abstraksi matematis siswa dalam menyelesaikan soal pada materi segiempat VII SMP.

\section{METODE}

Pendekatan yang digunakan dalam penelitian ini adalah pendekatan kualitatif dengan jenis deskriptif. Peneliti menggunakan metode kualitatif karena peneliti ingin melakukan penelitian pada kondisi yang alamiah yaitu tentang analisis kemampuan abstraksi matematis siswa pada materi segiempat kelas VII SMP. Subjek penelitian yaitu 3 siswa kelas VII-A MTs Persiapan yang dipilih secara purposive sampling. Pemilihan subjek penelitian didasarkan pada tingkat kemampuan matematis siswa yaitu tingkat tinggi, sedang, dan rendah.

Teknik pengumpulan data dalam penelitian ini, yaitu dengan menggunakan: (1) tes, tes yang digunakan dalam penelitian ini berupa tes uraian. pemberian tes dilakukan 2 tahap, Pemberian tes tahap I, diberikan kepada seluruh siswa kelas VII-A MTs Persiapan yang bertujuan untuk mengetahui tingkat kemampuan abstraksi siswa dan sebagai dasar pemilihan subjek penelitian. Pemberian tes tahap II, diberikan kepada 3 subjek penelitian yang telah dipilih. Tes ini bertujuan untuk mendeskripsikan kemampuan abstraksi siswa. (2) wawancara, kegiatan wawancara dalam penelitian ini dilakukan setelah pemberian soal tes tahap II. Wawancara ini ditujukan kepada 3 siswa yang menjadi subjek penelitian. Tujuan wawancara ini adalah untuk menemukan permasalahan secara lebih terbuka dengan minta pendapat, dan ide-idenya. Dalam kegiatan wawancara, peneliti menggunakan jenis wawancara semi terstruktur.

Dalam penelitian ini, uji kredibilitas data dilakukan dengan triangulasi teknik, yaitu dengan cara membandingkan data hasil tes tertulis dengan hasil wawancara sehingga diperoleh data yang kredibel. Setelah dieroleh data yang kredibel kemudian dilakukan analisis 
data. Adapun analisis data terdiri dari tiga alur kegiatan yang terjadi secara bersamaan, yaitu: (1) reduksi data. (2) penyajian data, dan (3) verifikasi data.

\section{HASIL}

Berdasarkan hasil tes tahap I yang telah diberikan dari 26 siswa kelas VII-A MTs Persiapan untuk menentukan subjek penelitian terdapat 5 siswa memiliki kemampuan matematika tinggi, 15 memiliki kemampuan matematika sedang, dan 6 memiliki kemampuan matematika rendah. Dari masing-masing kelompok yaitu siswa yang memiliki kemampuan tinggi, sedang, dan rendah tersebut kemudian dipilih satu siswa yang dijadikan sebagai subjek penelitian.

Selanjutnya peneliti memberikan soal tes tahap II kepada ketiga subjek penelitian. Berikut kemampuan abstraksi matematis dalam menyelesaikan soal pada materi segiempat.

a. Hasil Tes Subjek 1

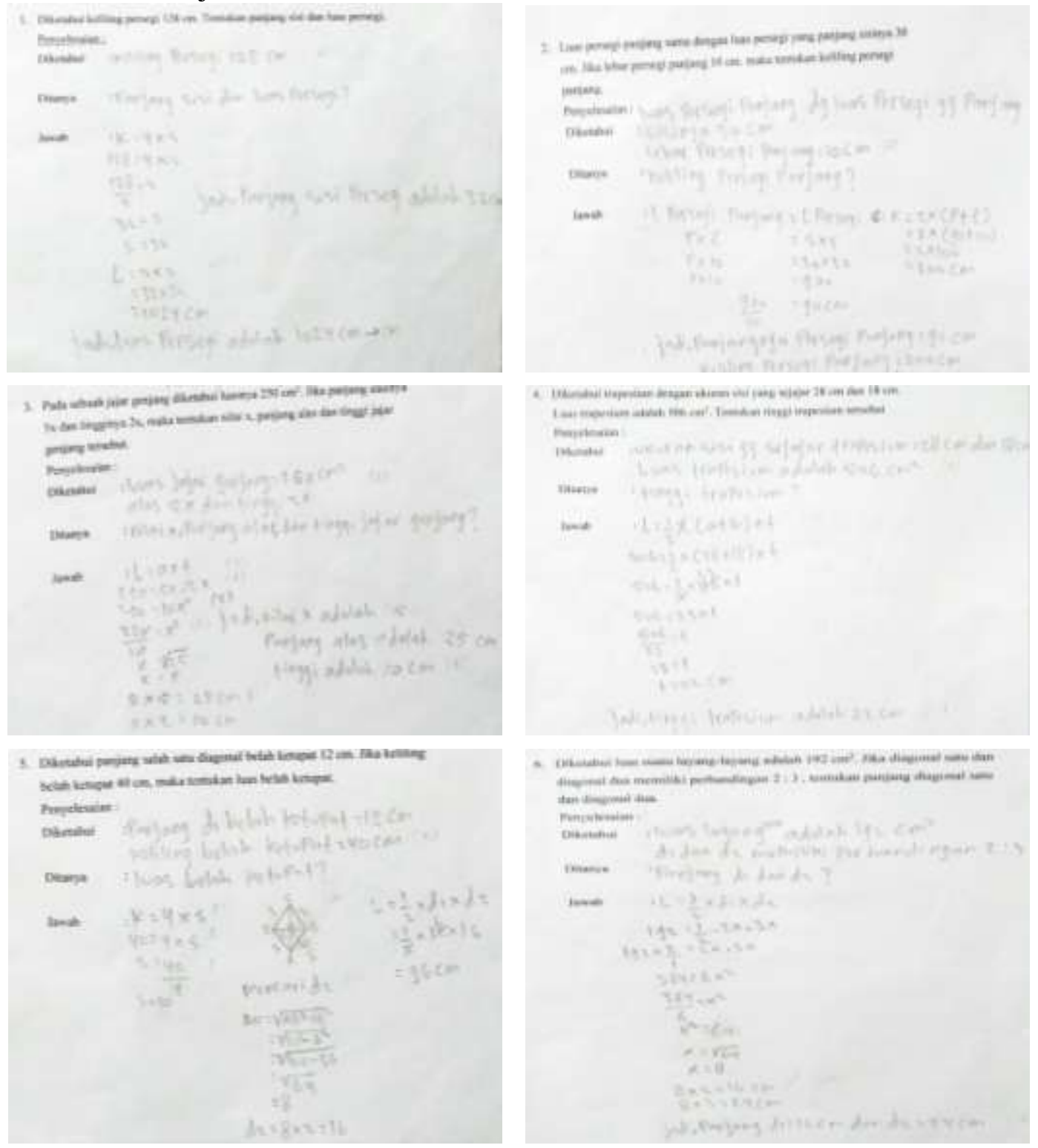

Gambar 1 Hasil Tes Subjek 1

Pada level pengenalan S1 mampu mengingat kembali aktivitas sebelumnya yang berkaitan dengan masalah. Pada tahap wawancara S1 mampu mengingat materi sebelumnya 
yang berkaitan dengan soal. Dari hasil tes, diketahui S1 mampu mengidentifikasi hal-hal yang diketahui pada soal 1, 2, 3, 4, 5 dan 6. S1 juga mampu menjelaskan apa saja yang diketahui dan ditanyakan pada ke enam soal dengan benar. Pada level representasi S1 mampu menyatakan hasil pemikirian sebelumnya dalam bentuk simbol matematika pada semua soal. Serta menjalankan metode solusi alternatif dengan benar. Sejalan dengan hasil wawancara, S1 mampu menjelaskan cara penyelesaian nomor 1, 2, 3, 4, 5 dan 6 dengan jawaban yang benar. Selanjutnya pada level abstraksi struktural menurut hasil data tes yang dikerjakan, S1mampu merefleksikan aktivitas sebelumnya kepada situasi baru dan mampu menyelesaikan soal pada nomor 1, 2, 3, 4, 5 maupun 6 dengan benar.

b. Hasil Tes Subjek 2
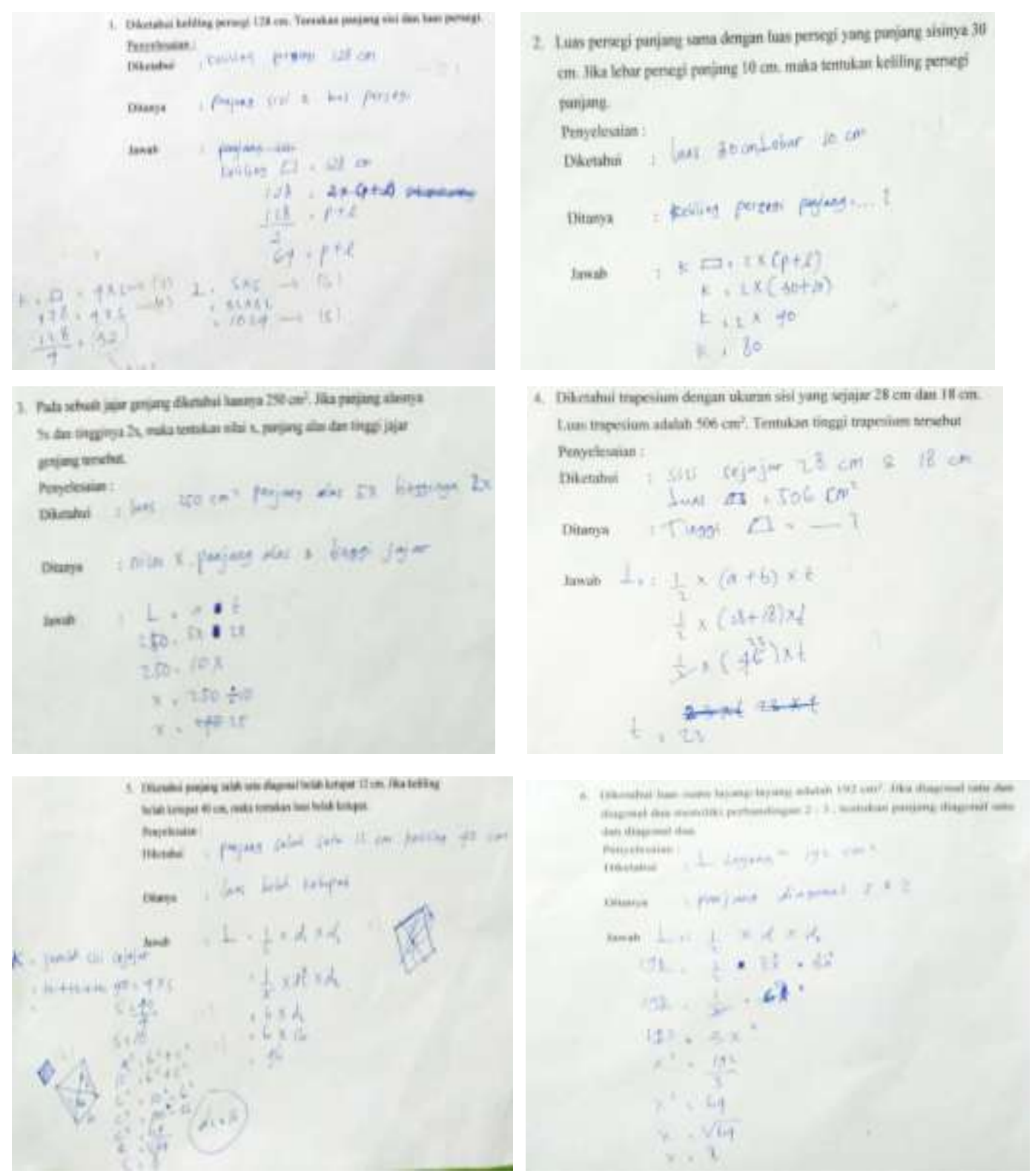

Gambar 2 Hasil Tes Subjek 2

Pada level pengenalan S2 mampu mengingat kembali aktivitas sebelumnya yang berkaitan dengan masalah. Pada data hasil tes soal nomor 1, 3, 4, 5 dan 6 S2 mampu mengidentifikasi hal-hal yang diketahui dalam soal dengan benar dan mengidentifikasi apa yang ditanyakan pada soal dengan benar. menyelesaikan soal nomor 1, 3, 4, 5 dan 6. Namun pada soal nomor 2, S2 belum mampu mengidentifikasi apa yang diketahui dalam soal. Dari 
hasil wawancara S2 mengaku bingung dalam memahami maksud soal nomor 2. Pada level representasi pada soal nomor 1, 4, 5, dan 6 dilihat dari data hasil tes S2 mampu menyatakan hasil pemikiran sebelumnya ke dalam simbol matematika. S2 juga mampu menjelaskan bagaimana cara melakukan penyelesaian soal dengan benar. Sedangkan pada nomor 2 dan 3 S2 mampu menyatakan masalah kedalam bentuk matematika berupa simbol tetapi S2 mengalami kesalahan dalam melakukan penyelesaian masalahnya. S2 mengalami kesulitan dalam memahami soal. Selanjutnya pada level abstraksi pada nomor 1 dan 5 S2 mampu merefleksikan aktivitas sebelumnya pada situasi baru, serta mampu mengembangkan strategi baru yang sebelumnya beum digunakan. Sedangkan pada nomor 2,3,4, dan 6 S2 tidak mampu merefleksikan aktivitas sebelumnya pada situasi baru serta tidak mampu menyelesaikan soal dengan benar, dikarenakan S2 mengalami kesulitan dalam menyelesaikan soal.

c. Hasil Tes Subjek 3
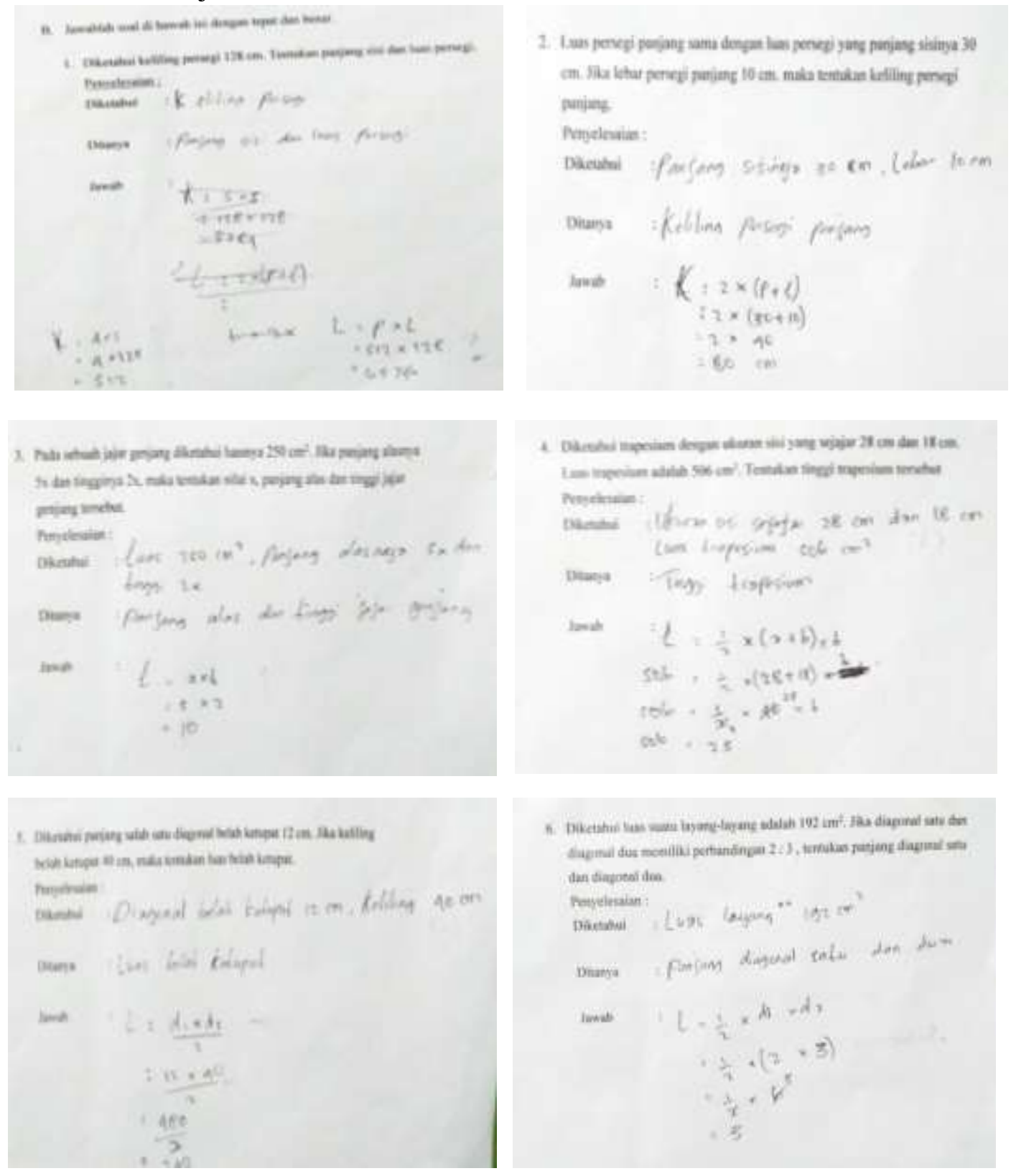

Gambar 3 Hasil Tes Subjek 3 
Pada level pengenalan soal nomor 1, 2, 3, 4, 5 dan 6 S3 mampu mengidentifikasi halhal yang diketahui dalam soal dengan benar dan mengidentifikasi apa yang ditanyakan pada soal dengan benar. Pada level representasi soal nomor 1, 2, 3, 4, 5, dan 6 S3 mampu menyatakan masalah ke dalam bentuk matematika berupa simbol. Tetapi S3 tidak mampu menjalankan metode solusi alternative dengan benar. S2 mengalami kesalahan dalam melakukan penyelesaian masalahnya. S2 tidak mampu menyelesaikan soal dengan jawaban yang benar. Selanjutnya pada level abstraksi pada nomor 1, 2, 3, 4, 5, dan 6 S3 tidak mampu merefleksikan aktivitas sebelumnya pada situasi baru, serta mengembangkan strategi baru untuk menyelesaikan masalah.

\section{PEMBAHASAN}

Dalam penelitian ini peneliti menganalisis kemampuan abstraksi matematis siswa pada siswa kelas VII MTs Persiapan. Adapun materi yang diujikan adalah bangun datar segi empat diantaranya persegi, persegi panjang, jajar genjang, trapesium, belah ketupat, dan layanglayang kelas VII semester genap. Dari 26 siswa dipilih tiga subjek yaitu siswa berkemampuan tinggi, siswa berkemampuan sedang, dan siswa berkemampuan rendah berdasarkan hasil tes tahap 1 yang dilakukan peneliti sebelum penelitian.

Dari hasil tes dan wawancara pada penelitian yang dilakukan diperoleh data berupa kemampuan abstraksi matematis siswa dalam menyelesaikan soal pada materi bangun datar segi empat. Adapun kemampuan abstraksi matematis berdasarkan level-level pada abstraksi yang dialami siswa berkemampuan tinggi, sedang, dan rendah disajikan pada tabel berikut. Tabel 1 Hasil Kemampuan Abstraksi Matematis

Kemampuan

Abstraksi

1. Level pengenalan

- Mengingat

kembali aktifitas sebelumnya yang

berkaitan dengan masalah yang dihadapi.

- Mengidentifikasi aktifitas sebelumnya yang berkaitan dengan masalah yang dihadapi.

2. Level Representasi

- Menyatakan hasil pemikiran sebelumnya dalam bentuk simbol matematika.

- Menjalankan metode solusi alternatif yang mungkin.

3. Level abstraksi

struktural
S1

S1 dapat mengingat

kembali aktivitas

sebelumnya yang

berkaitan dengan

masalah yang sedang

dihadapi, S1 juga

dapat

mengidentifikasi

aktifitas sebelumnya

yang berkaitan

dengan masalah yang

dihadapi.

\section{S1 dapat menyatakan}

hasil pemikiran

sebelumnya dalam

bentuk

simbol matematika, serta dapat menjalankan metode solusi alternatif yang mungkin.
S2

\section{S3}

S2 dapat mengingat S3 dapat mengingat

kembali aktivitas kembali aktivitas

sebelumnya yang sebelumnya yang

berkaitan dengan berkaitan dengan

masalah yang masalah yang

dihadapi, namun dihadapi, S3 juga

terdapat identifikasi dapat

yang tidak dapat mengidentifikasi

dilakukan oleh S2

yaitu pada soal nomor

2.

aktivitas

sebelumnya yang

berkaitan dengan

masalah yang

dihadapi

S2 dapat menyatakan

hasil pemikiran dalam

bentuk simbol, namun

dalam beberapa soal

S2 tidak mampu

menjalankan metode

solusi alternatif

S3 dapat

menyatakan hasil

pemikiran

sebelumnya dalam

bentuk simbol,

tetapi tidak dapat

menjalankan metode

solusi alternatif

dengan benar.
S1

merefleksikan

dapat $\mathrm{S} 2$

merefleksikan dapat S3 tidak dapat

merefleksikan 


\begin{tabular}{|c|c|c|c|c|}
\hline & $\begin{array}{c}\text { Kemampuan } \\
\text { Abstraksi }\end{array}$ & S1 & S2 & S3 \\
\hline - & $\begin{array}{l}\text { Merefleksikan } \\
\text { aktifitas } \\
\text { sebelumnya } \\
\text { kepada situasi } \\
\text { baru. } \\
\text { Mengembangkan } \\
\text { strategi untuk } \\
\text { suatu masalah }\end{array}$ & $\begin{array}{l}\text { aktivitas sebelumnya } \\
\text { pada situasi baru } \\
\text { serta mampu } \\
\text { mengembangkan } \\
\text { strategi baru untuk } \\
\text { suatu masalah, } \\
\text { dimana sebelumnya } \\
\text { belum digunakan. }\end{array}$ & $\begin{array}{l}\text { aktivitas sebelumnya } \\
\text { dan mengembangkan } \\
\text { strategi baru untuk } \\
\text { suatu masalah yaitu } \\
\text { pada nomor } 1 \text { dan } 5 .\end{array}$ & $\begin{array}{l}\text { aktivitas } \\
\text { sebelumnya pada } \\
\text { situasi baru serta } \\
\text { tidak dapat } \\
\text { mengembangkan } \\
\text { strategi baru untuk } \\
\text { suatu masalah. }\end{array}$ \\
\hline
\end{tabular}

\section{SIMPULAN DAN SARAN}

Berdasarkan hasil penelitian analisis kemampuan abstraksi matematis siswa pada materi segiempat siswa kelas VII-A MTs Persiapan Kabupaten Mojokerto, dapat disimpulkan sebagai berikut: (1) Siswa yang berkemampuan matematis tinggi dapat menggunakan kemampuan berfikir abstraksi dengan sangat baik. Dalam hal ini terlihat dari pencapaian pengukuran kemampuan abstraksi pada kriteria level-level abstraksi yang diberikan dalam penelitian, yaitu level pengenalan (recognition), level representasi (representation) dan level abstraksi struktural (structural abstraction). (2) Siswa yang berkemampuan matematis sedang belum tentu mampu menggunakan kemampuan berfikir abstraksi dengan baik. Berdasarkan pencapaian pengukuran kemampuan abstraksi yang diberikan dalam penelitian ini, siswa dapat mencapai semua kriteria di dua soal, yaitu level pengenalan (recognition), level representasi (representation) dan level abstraksi struktural (structural abstraction). Namun di empat soal yang lain siswa hanya dapat menerapkan 2 kriteria saja yaitu level pengenalan (recognition) dan level representasi (representation). (3) Siswa yang berkemampuan matematis rendah dalam menggunakan kemampuan berpikir abstraksi masih kurang baik. Berdasarkan pengukuran kemampuan berpikir abstraksi yang ada dalam penelitian ini siswa hanya dapat menerapkan pada level pengenalan (recognition) saja dalam menyelesaikan soal yang diberikan.

Dengan adanya penelitian ini, guru hendaknya meningkatkan kemampuan abstraksi matematis siswa dalam menyelesaikan soal. Bagi siswa yang memiliki kemampuan abstraksi rendah, hendaknya guru berupaya meningkatkan kemampuan abstraksi siswa dengan memberikan lebih banyak latihan-latihan dalam diskusi. Dalam meningkatkan kemampuan abstraksi matematis bisa melalui berbagai cara. Salah satunya dengan menerapkan pembelajaran kooperatif tipe STAD. Dengan penerapan model pembelajaran kooperatif tipe STAD, semua siswa aktif mengerjakan tugas, siswa yang kurang mampu bertanya pada temannya yang lebih mampu demikian juga siswa dengan kemampuan abstraksi tinggi akan berusaha mengajarkan temannya yang kurang mampu.

\section{DAFTAR RUJUKAN}

Gray, E. \& Tall, D. (2007). Abstraction as a Natural Process of Mental Compression. Mathematics Education Research Journal, 19(2), 23-40.

Hasanah, N. (2010). Abstraksi Siswa SMP dalam Belajar Geometri melalui Penerapan Model van Hiele dan Geometer's Sketchpad. Tesis tidak diterbitkan. Bandung: Universitas Pendidikan Indonesia.

Hong \& Kim. (2016). Mathematical Abstraction The Solving ill-Structured Problems by Elementary School Students in Korea. Eurasia Journal of Matemhatics, Science \& Technology Education, 12(2), 267-281.

Moleong, L. J. (2013). Metodologi Penelitian Kualitatif. Bandung: PT Remaja Rosdakarya. 
Tall, D. (2002). Advanced Mathematical Thinking Mathematics Education Library. Dordrecht: Kluwer Academic Publishers.

Wiryanto. (2014). Level-level Abstraksi dalam Pemecahan Masalah Matematika. Jurnal Pendidikan Teknik Elektro, 3(3). 